S6 Table. Causality framework evidence for Zika virus infection and Guillain-Barré syndrome

Contents

S6 Table. Causality framework evidence for Zika virus infection and Guillain-Barré syndrome …....................................................................................

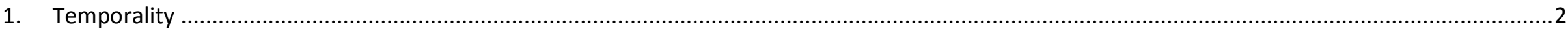

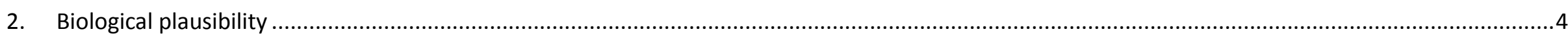

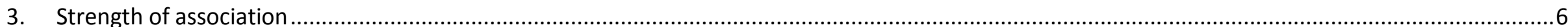

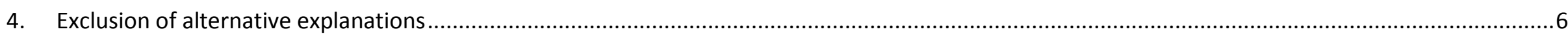

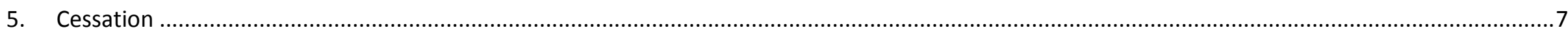

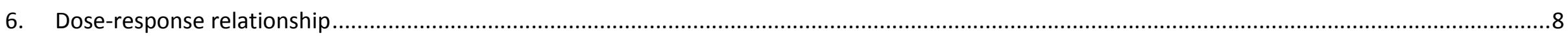

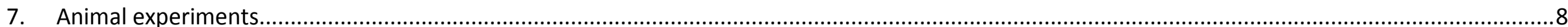

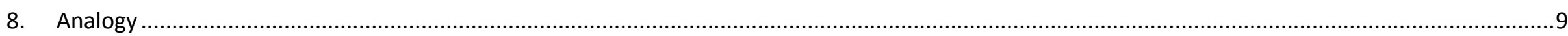

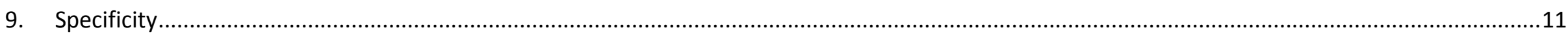

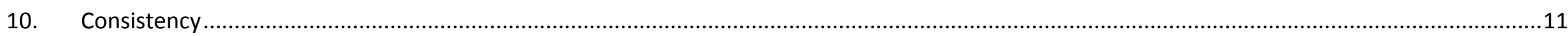

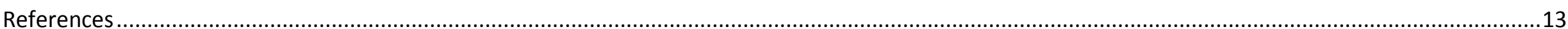




\begin{tabular}{|c|c|c|c|c|c|c|c|}
\hline $\begin{array}{l}\text { Question } \\
\text { no. }\end{array}$ & $\begin{array}{l}\text { Causality dimension and } \\
\text { question }\end{array}$ & $\begin{array}{c}\text { Study type, } \\
\text { number of primary } \\
\text { items [reference] } \\
\text { of included items }\end{array}$ & $\begin{array}{l}\text { Linked } \\
\text { items }\end{array}$ & Country of study & $\begin{array}{l}\text { Support } \\
\text { causality } \\
\text { dimension }\end{array}$ & \begin{tabular}{|c|} 
Do not \\
support \\
causality \\
dimension
\end{tabular} & Summary of evidence \\
\hline \multicolumn{2}{|c|}{ 1. Temporality } & \multicolumn{6}{|c|}{$\begin{array}{l}\text { Summary: Total, } 31 \text { studies in } 26 \text { groups. Reviewer assessments found sufficient evidence for all } 3 \text { questions of an appropriate } \\
\text { temporal relationship between Zika virus (ZIKV) infection and Guillain-Barré syndrome (GBS). The time interval between ZIKV } \\
\text { symptoms and onset of neurological symptoms was compatible with that of other accepted triggers of GBS. }\end{array}$} \\
\hline $1.1 \mathrm{a}$ & $\begin{array}{l}\text { Does ZIKV infection precede the } \\
\text { development of GBS in } \\
\text { individuals? }\end{array}$ & $\begin{array}{c}\text { Case report, } 4 \\
\text { [110, 111, 117, } \\
120] \\
\text { Case series, } 4 \text { [105, } \\
\text { 106, 108]; } \\
\text { Case-control study, } \\
1 \text { [112] }\end{array}$ & $\begin{array}{c}{[121]} \\
\text { linked to } \\
{[120]} \\
{[102,} \\
116] \\
\text { linked to } \\
{[112]}\end{array}$ & $\begin{array}{c}\text { Brazil, } \\
\text { El Salvador, } \\
\text { Panama, Puerto } \\
\text { Rico, Venezuela, } \\
\text { French Polynesia, } \\
\text { United States }^{\mathrm{a}} \text {, } \\
\text { Netherlands }^{\mathrm{a}}\end{array}$ & 9 & 0 & $\begin{array}{l}\text { The exposure was reported before the outcome in } \\
\text { studies in Brazil, El Salvador, Panama, Puerto Rico, } \\
\text { Venezuela, in French Polynesia, and in returning } \\
\text { travellers: } \\
\text { - The first case was reported during the 2013-14 ZIKV } \\
\text { outbreak in French Polynesia. An influenza-like illness } \\
\text { occurred } 7 \text { days before the onset of GBS symptoms. } \\
\text { ZIKV RT-PCR was negative on day } 8 \text {. Serology on days } \\
8 \text { and } 28 \text { suggested recent ZIKV infection (IgM } \\
\text { positive) and past dengue virus (DENV) infection (IgG } \\
\text { positive) [102]; } \\
\text { - } 83 \text { of } 112 \text { patients (74\%) with GBS reported ZIKV- } \\
\text { related symptoms before the onset of GBS } \\
\text { symptoms, of which } 53 \text { cases (all except } 42 \text { cases in } \\
\text { Brazil and all cases in El Salvador) were laboratory } \\
\text { confirmed ZIKV infections [105, 106, 108, 110-112, } \\
120] \text {. }\end{array}$ \\
\hline $1.1 b$ & $\begin{array}{l}\text { Is there a consistent time- } \\
\text { dependent relationship between } \\
\text { the occurrence of ZIKV cases and } \\
\text { cases with GBS at population- } \\
\text { level? }\end{array}$ & $\begin{array}{c}\text { Ecological } \\
\text { study/outbreak } \\
\text { report, } 16[55-57 \\
67,100,104,107 \\
109,115]\end{array}$ & $\begin{array}{c}{[103,} \\
122] \\
\text { linked to } \\
{[104]}\end{array}$ & $\begin{array}{l}\text { Brazil, Colombia, } \\
\text { Dominican } \\
\text { Republic, } \\
\text { El Salvador, } \\
\text { French Guiana, } \\
\text { Haiti, Honduras, } \\
\text { Martinique, } \\
\text { Panama, } \\
\text { Paraguay, Puerto } \\
\text { Rico, Suriname, } \\
\text { Venezuela, } \\
\text { Micronesia, }\end{array}$ & 9 & (1) & $\begin{array}{l}\text { Studies at the population level report differing findings } \\
\text { about the temporal relationship between reported } \\
\text { cases of Zika-like illness and GBS cases: } \\
\text { - In } 9 \text { countries (Brazil, Colombia, Dominican Republic, } \\
\text { El Salvador, French Polynesia, Honduras, Paraguay, } \\
\text { Suriname and Venezuela) an increase of GBS cases } \\
\text { was observed during the ZIKV epidemic [56, 57, 67, } \\
104,107,109] \text {. In Brazil, the number of cases } \\
\text { recorded in } 2015 \text { was } 19 \% \text { higher than in the previous } \\
\text { year [57]; } \\
\text { - In Haiti, French Guiana, Federal States of Micronesia } \\
\text { (Yap), Panama, Puerto Rico, and Martinique there }\end{array}$ \\
\hline
\end{tabular}




\begin{tabular}{|c|c|c|c|c|c|c|c|}
\hline & & & & $\begin{array}{l}\text { French Polynesia, } \\
\text { Pacific Islands }\end{array}$ & & & $\begin{array}{l}\text { was no increase in GBS cases above the background } \\
\text { level }[55,57,67,109] \text { or no increase in } \\
\text { hospitalisations during the epidemic [100] } \\
\text { - } 1 \text { study examined reports of acute flaccid paralysis } \\
\text { (AFP) collected for polio surveillance in children in } \\
\text { several Pacific Islands as a possible signal of GBS } \\
\text { cases [115]. An increase above the expected annual } \\
\text { number of AFP cases in the same year as a ZIKV } \\
\text { outbreak was only seen in the Solomon Islands. In } \\
\text { most islands the expected number of cases was }<1 \\
\text { per year, however. }\end{array}$ \\
\hline
\end{tabular}


might be shorter, as observed in other outbreaks

\section{Biological plausibility}

Do ZIKV epitopes mimic host antigens (molecular mimicry)?

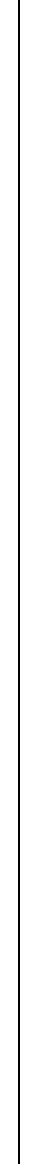

Summary: Total, 6 items in 4 groups reviewed. Reviewer assessments found sufficient evidence for 2 of 3 questions about biologically plausible mechanisms by which ZIKV could trigger the immune-mediated pathology of GBS. There is evidence that supports a role for molecular mimicry, a proposed mechanism of autoimmunity in the development of GBS, which has been reported in Campylobacter jejuni-associated GBS. Direct neurotropic effects of ZIKV might also occur.

\begin{tabular}{l|l|l|l|l|l} 
Case-control study, $[102$, & French Polynesia & 3 & 0 & Evidence for molecular mimicry comes from 2 in silico
\end{tabular} 1 [112]; Sequence 116]

analysis and linked to

phylogenetics, $2 \quad[112]$

approaches and 1 clinical study:

- Analysis of peptide sharing between the ZIKV (de-myelination or axonal neuropathy) and human polyprotein and human proteins related to myelin autoantigens known to be involved in GBS identified 99 candidate proteins with epitope sharing, of which many have been shown to be involved in

autoimmune disease [114];

- The prediction of B-cell epitopes of ZIKV and the comparison to B-cell epitopes in the human proteome identified several candidate proteins for both a Brazilian (Asian lineage) and African ZIKV strain. The proteins with the highest probability were Optineurin, Synaptogyrin-1, von Willebrand factor A Pro-neuropeptide $Y$, Neuron Navigator $Y$ (Brazilian strain only). 3D modelling of the ZIKV Brazil

polyprotein showed matches for Pro-neuropeptide $Y$, Synaptogyrin, Neurotrophin 4, neural cell adhesion molecule, and von Willebrand factor A for a ZIKV region adjacent to high affinity $\mathrm{MHC}$ II binding site suggesting $B$ and T-cell co-presentation. These findings suggest that antibodies against ZIKV may also target host proteins involved in neurologic and haemostatic processes [54];

- IgM/IgG containing serum samples from GBS patients in French Polynesia were evaluated for reactivity to glycolipids using ELISA and combination microarray screening. 13 (31\%) of GBS patients showed positive reactivity to glycolipids at admission and 10 (24\%) 


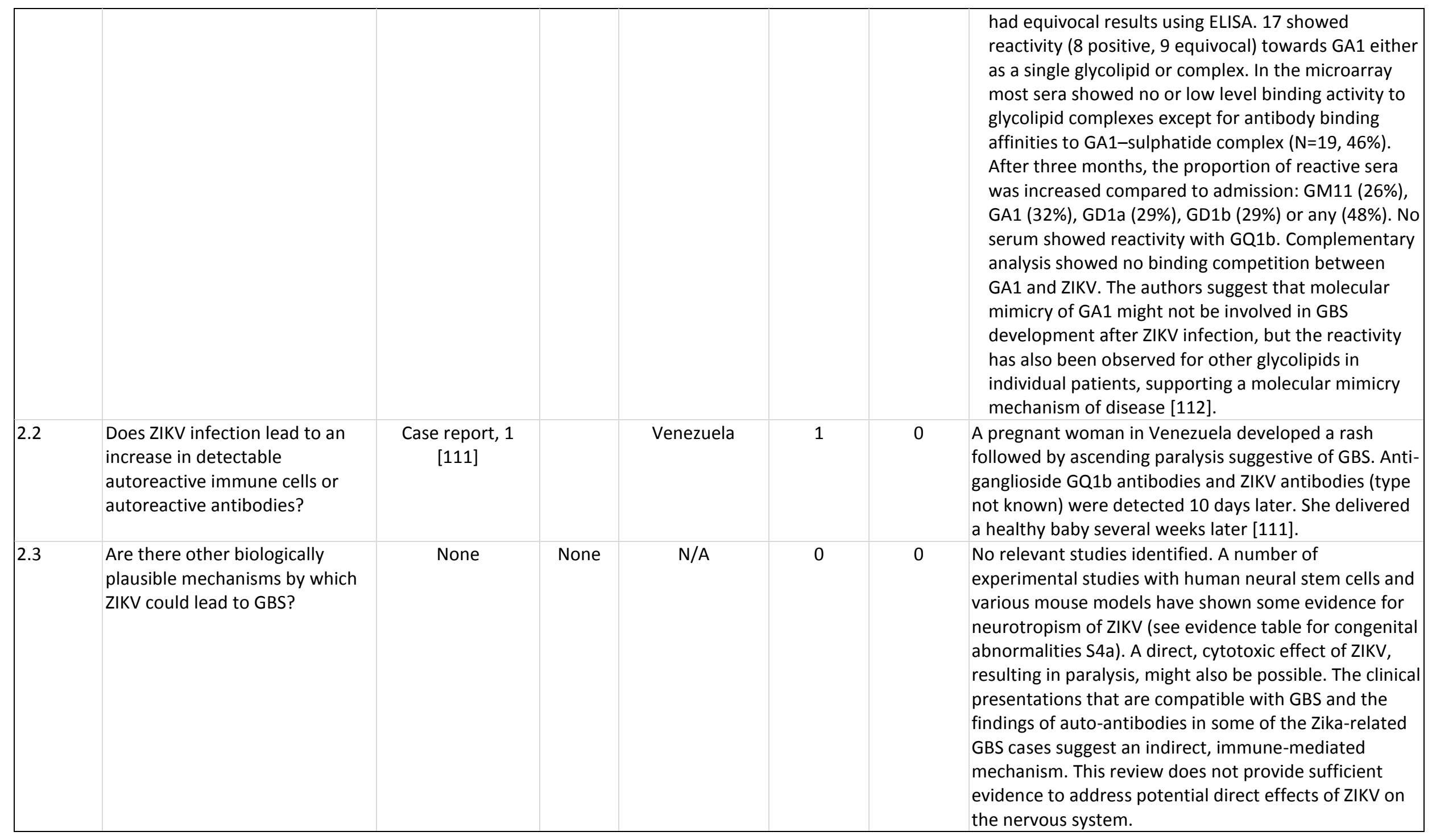


3. Strength of association

3.1 How strong is the association between ZIKV infection and GBS at the individual level?

How strong is the association between ZIKV infection and GBS at the population level?

\section{Exclusion of alternative} explanations

\subsection{Have other} explanations/confounders of the association between ZIKV infection and GBS been

Summary: Total 7 items in 2 groups reviewed. The reviewers assessed evidence from the ZIKV outbreak in French Polynesia as showing a strong association between ZIKV and GBS at both the individual and population level. Surveillance reports from Brazil also support an association at the population level.

\begin{tabular}{c|c|}
\hline Case-control study, & {$[102$,} \\
$1[112]$ & $116]$ \\
& linked to \\
& {$[112]$}
\end{tabular}

1

\begin{tabular}{c|c|c|}
$\begin{array}{c}\text { Ecological } \\
\text { study/outbreak } \\
\text { report: } 2 \text { [101] } \\
\text { [122] }\end{array}$ & $\begin{array}{c}\text { [103, } \\
\text { linked to }\end{array}$ & $\begin{array}{c}\text { Brazil, French } \\
\text { Polynesia }\end{array}$ \\
\hline [122] & \\
\hline
\end{tabular}

1

(1)

Polynesia

2
0

1 case-control study with 42 GBS cases and 98 using age-, sex-, and residence-matched hospital controls. A crude OR of $59.7(95 \% \mathrm{Cl} 10.4-\infty)$ was estimated for GBS cases being ZIKV IgM or IgG positive compared to controls and an OR of 34.1 ( $95 \% \mathrm{Cl} 5.9-\infty)$ for GBS cases being ZIKV plaque reduction neutralisation test (PRNT) positive compared with controls [112].

0 The same 42 cases of GBS in French Polynesia were analysed with a population denominator (all items about the French Polynesia outbreak are considered as part of a single group). The incidence of GBS during the epidemic ( 0.41 per 1000 person years (py, $95 \% \mathrm{Cl} 0.29$ $0.5)$ in French Polynesia was 21 times higher than in the pre-Zika period of 2009 to 2012 vs. 0.02 per 1000 py, $95 \% \mathrm{Cl} 0.01$ to 0.03$)$. The authors calculated an attributable risk of 0.39 per 1000 py [104]. Same case data as above, population-based analysis.

Hospital-based surveillance data from Brazil showed 1708 reports of GBS from January to November in 2015, a 19\% increase compared with 2014 [101]. Several states reported increases in 2015 vs. 2014, e.g. Alagoas (516.7\%), Bahia (196.1\%), Rio Grande do Norte (108.7\%), Piauí (108.3\%), Espirito Santo (78.6\%), and Rio de Janeiro (60.9\%); others reported stable or lower numbers.

Summary: Total, 10 items in 7 groups studies reviewed. Reviewer assessments found sufficient evidence at the individual level that other infectious triggers of GBS have been excluded; no other single infection could have accounted for clusters of GBS. The evidence about other exposures could not be assessed because of an absence of relevant studies
Case report, 6
[121] Brazil, Haiti,
7
$[110,113,117-\quad$ linked to Martinique,
Some studies in Brazil, French Polynesia, Puerto Rico,
120]; Case-control [120] Netherlands ${ }^{a}$
study, 1 [112] [102, Puerto Rico, Martinique, Haiti and a traveller returning from Suriname to the Netherlands excluded other acute infections:

116] French Polynesia 


\begin{tabular}{|c|c|c|c|c|c|}
\hline & $\begin{array}{l}\text { excluded, such as other } \\
\text { infections? }\end{array}$ & $\begin{array}{c}\text { linked to } \\
\text { [112] }\end{array}$ & & & $\begin{array}{l}\text { - } 5 \text { studies excluded acute dengue virus (DENV) } \\
\text { infection [110, 112, 113, 117, 118] by IgM serology, } \\
\text { DENV antigens and/or DENV RT-PCR in } 48 \text { individuals. } \\
\text { However, } 44 \text { of } 46 \text { tested cases were IgG positive for } \\
\text { DENV (see 'co-factors'); } \\
\text { - } 5 \text { studies excluded acute chikungunya (CHIKV) } \\
\text { infection GBS by IgM serology and/or CHIKV RT-PCR } \\
\text { in } 6 \text { individuals [110, 113, 117, 118, 120]; } \\
\text { - Only } 2 \text { studies (including } 1 \text { case-control) excluded } \\
\text { infection with C. jejuni, Mycoplasma pneumoniae, } \\
\text { Epstein-Barr virus (EBV) and herpes simplex virus } \\
\text { (HSV) in } 44 \text { individuals }[112,113] \text {. }\end{array}$ \\
\hline 4.2 & $\begin{array}{l}\text { Have other } \\
\text { explanations/confounders of the } \\
\text { association between ZIKV } \\
\text { infection and GBS been } \\
\text { excluded, such as vaccines? }\end{array}$ & & 0 & 0 & No relevant studies identified \\
\hline 4.3 & $\begin{array}{l}\text { Have other } \\
\text { explanations/confounders of the } \\
\text { association between ZIKV } \\
\text { infection and GBS been } \\
\text { excluded, such as underlying } \\
\text { systemic disease? }\end{array}$ & & 0 & 0 & No relevant studies identified \\
\hline 4.4 & $\begin{array}{l}\text { Have other } \\
\text { explanations/confounders of the } \\
\text { association between ZIKV } \\
\text { infection and GBS been } \\
\text { excluded, such as concomitant } \\
\text { medication, drugs or other } \\
\text { chemicals? }\end{array}$ & & 0 & 0 & No relevant studies identified \\
\hline \multicolumn{2}{|c|}{ 5. Cessation } & \multicolumn{4}{|c|}{$\begin{array}{l}\text { Summary: Total } 8 \text { items in } 6 \text { groups reviewed. Reviewer assessments found sufficient evidence for } 1 \text { of } 3 \text { questions. In one state } \\
\text { in Brazil, four other countries in the Americas and in French Polynesia, reports of GBS decreased after ZIKV transmission ceased. } \\
\text { Evidence for the other questions could not be assessed because no relevant studies were identified. }\end{array}$} \\
\hline 5.1 & $\begin{array}{l}\text { Does the intentional } \\
\text { prevention/removal/elimination } \\
\text { of ZIKV infection in individuals, }\end{array}$ & & 0 & 0 & No relevant studies identified \\
\hline
\end{tabular}




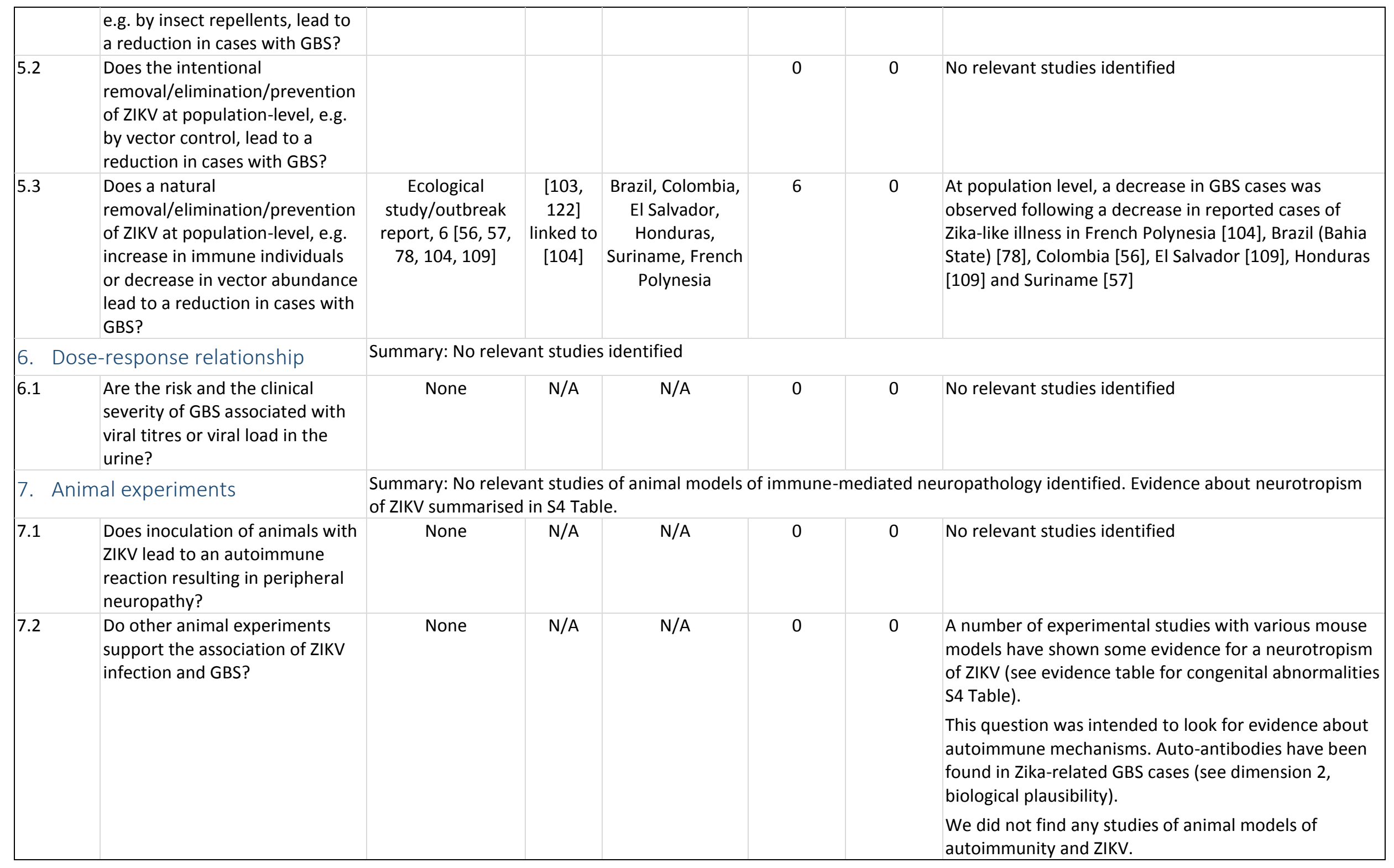


8. Analogy

8.1

Do other flaviviruses or

arboviruses cause GBS and by

which mechanism(s)?
Summary: Selected studies reviewed for 2 of 3 questions. Analogous mosquito-borne neurotropic flavivirus infections have been reported in association with GBS (West Nile virus, WNV; DENV; Japanese encephalitis virus, JEV). WNV and JEV have also been reported to be associated with direct neurotropic effects and poliomyelitis-like acute flaccid paralysis. The time lag between ZIKV symptoms and GBS symptoms is analogous to intervals reported for other infectious triggers of GBS. There is some evidence that, as for $C$. jejuni-associated GBS, molecular mimicry could be involved. Evidence was not reviewed systematically.

\begin{tabular}{|c|c|c|c|c|c|}
\hline $\begin{array}{l}\text { Studies not found } \\
\text { through systematic }\end{array}$ & N/A & $\mathrm{N} / \mathrm{A}$ & N/A & N/A & $\begin{array}{l}\text { Evidence about GBS following mosquito-borne } \\
\text { flavivirus infections (WNV, DENV, JEV). }\end{array}$ \\
\hline
\end{tabular}

searches

- WNV: A population-based study identified cases of acute paralysis following an outbreak of WNV in Colorado, USA in 2003 in an area of 724,000 residents. Of 32 cases with acute paralysis and WNV infection confirmed by serum IgM, only 6 (19\%) had paralysis alone whereas the others had concomitant encephalitis or meningitis. 27 cases (84\%) had asymmetric weakness consistent with poliomyelitislike syndrome (19 with cranial nerve involvement), 4 (13\%) had symmetric ascending weakness with sensory abnormalities consistent with GBS and 1 had thoracic nerve paralysis. 26 patients $(81 \%)$ reported no underlying morbidity. In the cases with poliomyelitis-like paralysis, the median latency between WNV infection symptoms and onset of paralysis was 3 days (range $0-18$ days) and electromyographic studies suggested involvement of the anterior horn cells. The electromyographic findings in the GBS patients were indicative of demyelinating sensorimotor neuropathy [129]. In an in vitro experiment the infection of rat Schwann cells with WNV led to an upregulation of MHC class I and II molecules suggesting that Schwann cells may act as antigen presenting cells and bind to immune cells leading to peripheral nerve cell damage [135].

- A narrative review identified 247 studies about neurological complications of DENV infection, of 


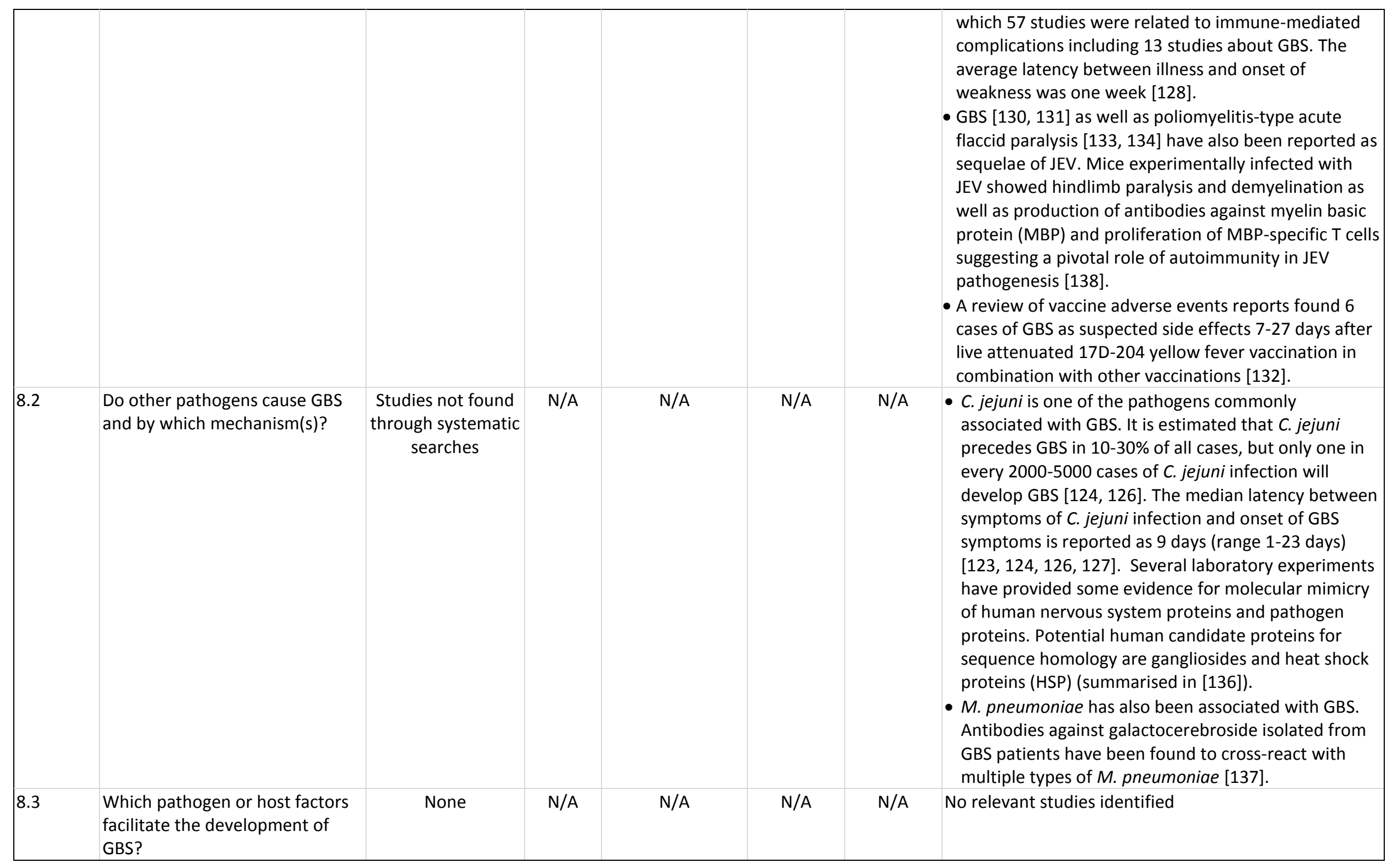




\section{Specificity}

9.1 Are there pathological findings in cases with GBS that are specific for ZIKV infection?

10. Consistency

Is the association between ZIKV infection and cases with GBS consistently found across different geographical regions?

Summary: 0 items reviewed. No relevant studies identified

\begin{tabular}{|c|c|c|c|c|c|}
\hline None & $\mathrm{N} / \mathrm{A}$ & N/A & 0 & 0 & No relevant studies identified \\
\hline
\end{tabular}

Summary: For 3 of 4 questions, there was sufficient evidence of consistency. By geographical region, ZIKV transmission has been associated with the occurrence of GBS in 2 of 3 regions where ZIKV has circulated since 2007. By study design, the association between ZIKV infection and GBS has been found in studies at both individual and population level and with both retrospective and prospective designs. By population group, ZIKV infection has been linked to GBS in both residents of an affected country and travellers from non-affected countries whose only possible exposure to ZIKV was having travelled to an affected country. The evidence according to ZIKV lineage is unclear because an association between ZIKV and GBS has only been reported from countries with ZIKV of the Asian lineage since 2013.

None N/A

N/A .
N/A

- Reports of GBS in association with ZIKV transmission have been made in two regions with ZIKV

transmission since 2007: Pacific (French Polynesia) and the Americas (Brazil, Colombia, Dominican

Republic, El Salvador, Honduras, Paraguay, Surinam, Venezuela) and in travellers returning from the Americas. In some of these countries clusters of cases have occurred but in others isolated individual cases without a population-level increase have been reported.

- Cross-sectional studies from different countries in Africa and Asia from 1945-2014 showed ZIKV seroprevalence of $0.6-64 \%$ in African countries and 2.3-75\% in Asian countries [99] suggesting that ZIKV might have been endemic in several countries for many years. No reports identified that indicated increased numbers of cases of GBS above baseline levels in these countries. Possible explanations include small case numbers or population size, poor surveillance, high levels of immunity to ZIKV, or a lack of an association.

- The fact that we observe GBS both in travellers to as well as residents of ZIKV affected countries shows that the association can be made across populations 


\begin{tabular}{|c|c|c|c|c|c|c|}
\hline & $\begin{array}{l}\text { different } \\
\text { populations/subpopulations? }\end{array}$ & & & & & $\begin{array}{l}\text { with a possibly different lifetime exposure to other } \\
\text { infectious or other agents possibly leading to GBS } \\
{[108,120]} \\
\text { - No relevant studies found to have examined the } \\
\text { association in different subpopulations within a } \\
\text { country, e.g. by ethnic group. }\end{array}$ \\
\hline 10.3 & $\begin{array}{l}\text { Is the association between ZIKV } \\
\text { infection and cases with GBS } \\
\text { consistently found across } \\
\text { different ZIKV lineages/strains? }\end{array}$ & None & N/A & N/A & $\mathrm{N} / \mathrm{A}$ & $\begin{array}{l}\text { The data on differential pathogenicity by ZIKV strain or } \\
\text { lineage is inconsistent to date: } \\
\text { - Several countries in Africa, where the African lineage } \\
\text { ZIKV is presumably endemic have not reported GBS } \\
\text { as a complication of ZIKV infection. Differences in the } \\
\text { sensitivity of surveillance systems between countries } \\
\text { that have and have not reported cases have not been } \\
\text { examined. } \\
\text { - An increase in reports of GBS has only been reported } \\
\text { from countries in which Asian lineage ZIKV } \\
\text { transmission has been found for the first time. These } \\
\text { differences may be true or confounded by differential } \\
\text { surveillance and/or population sizes. This hypothesis } \\
\text { cannot be supported nor rejected to date. }\end{array}$ \\
\hline
\end{tabular}

Abbreviations: AFP, acute flaccid paralysis; CHIKV, chikungunya virus; CMV, cytomegalovirus; DENV, dengue virus; HSV, herpes simplex virus; hiPSC, human induced pluripotent stem cells; hnPC, human neural progenitor cell; IHC, immunohistochemistry; JEV, Japanese encephalitis virus; miRNA, micro RNA; NSC, neuronal stem cell; PRNT, plaque reduction neutralisation test; qPCR, quantitative PCR; RT-PCR, reverse transcriptase PCR, RR, risk ratio; WNV; West Nile virus; ZIKV, Zika virus. 


\section{References}

\section{[1-53 not part of this body of evidence]}

54. Homan J, Malone RW, Darnell SJ, Bremel RD. Antibody mediated epitope mimicry in the pathogenesis of Zika virus related disease. 2016. Available from: http://biorxiv.org/content/biorxiv/early/2016/03/19/044834.full.pdf. Cited 9 November 2016.

55. Pan American Health Organization. Epidemiological Alert. Zika virus infection 24 March 2016. 2016. Available from:

http://www.paho.org/hq/index.php?option=com_docman\&task=doc_view\&ltemid=270\&gid=33937\&lang=en. Last accessed 17.08.2016.

56. Pan American Health Organization. Epidemiological Alert. Zika virus infection 08 April 2016. 2016. Available from:

http://www.paho.org/hq/index.php?option=com_docman\&task=doc_view\&ltemid=270\&gid=34144\&lang=en. Last accessed 17.08.2016.

57. Pan American Health Organization. Epidemiological Update. Zika virus infection - 28 April 2016. 2016. Available from:

http://www.paho.org/hq/index.php?option=com_docman\&task=doc_view\&ltemid=270\&gid=34327\&lang=en. Last accessed 17.08.2016.

[58-66 not part of this body of evidence]

67. Pan American Health Organization. Epidemiological Alert. Zika virus infection 31 March 2016. 2016. Available from:

http://www.paho.org/hq/index.php?option=com_docman\&task=doc_view\&ltemid=270\&gid=34041\&lang=en. Last accessed 17.08.2016.

[68-77 not part of this body of evidence]

78. Paploski IA, Prates AP, Cardoso CW, Kikuti M, Silva MM, Waller LA, et al. Time Lags between Exanthematous Illness Attributed to Zika Virus, GuillainBarre Syndrome, and Microcephaly, Salvador, Brazil. Emerg Infect Dis. 2016;22(8):1438-44. Epub 2016/05/05. doi: 10.3201/eid2208.160496. PubMed PMID: 27144515.

[79-99 not part of this body of evidence]

100. Duffy MR, Chen TH, Hancock WT, Powers AM, Kool JL, Lanciotti RS, et al. Zika virus outbreak on Yap Island, Federated States of Micronesia. N Engl J Med. 2009;360(24):2536-43. Epub 2009/06/12. doi: 10.1056/NEJMoa0805715. PubMed PMID: 19516034.

101. World Health Organization WHO. Zika situation report. Neurological syndrome and congenital anomalies - 5 February 2016. 2016. Available from: http://apps.who.int/iris/bitstream/10665/204348/1/zikasitrep_5Feb2016_eng.pdf?ua=1. Last accessed 26.10.2016. 
102. Oehler E, Watrin L, Larre P, Leparc-Goffart I, Lastere S, Valour F, et al. Zika virus infection complicated by Guillain-Barre syndrome--case report, French Polynesia, December 2013. Euro Surveill. 2014;19(9). Epub 2014/03/15. PubMed PMID: 24626205.

103. Institut de veille sanitaire. Virus Zika Polynésie 2013-2014, lle de Yap, Micronésie 2007 - Janvier 2014. 2014. Available from:

http://www.invs.sante.fr/Publications-et-outils/Points-epidemiologiques/Tous-les-numeros/International/Virus-Zika-en-Polynesie-2013-2014-et-ile-de-YapMicronesie-2007-Janvier-2014. Last accessed 17.8.16.

104. Ioos S, Mallet HP, Leparc Goffart I, Gauthier V, Cardoso T, Herida M. Current Zika virus epidemiology and recent epidemics. Med Mal Infect. 2014;44(7):302-7. Epub 2014/07/09. doi: 10.1016/j.medmal.2014.04.008. PubMed PMID: 25001879.

105. Pan American Health Organization. Epidemiological Update. Neurological syndrome, congenital anomalies, and Zika virus infection - 17 January 2016. 2016. Available from: http://www.paho.org/hq/index.php?option=com_docman\&task=doc_view\&ltemid=270\&gid=32879\&lang=en. Last accessed 17.08 .2016 .

106. Pan American Health Organization. Epidemiological Alert. Zika virus infection -3 March 2016. 2016. Available from:

http://www.paho.org/hq/index.php?option=com_docman\&task=doc_view\&ltemid=270\&gid=33486\&lang=en. Last accessed 17.08.2016.

107. Pan American Health Organization. Epidemiological Alert. Zika virus infection -10 March 2016. 2016. Available from:

http://www.paho.org/hq/index.php?option=com_docman\&task=doc_view\&ltemid=270\&gid=33659\&lang=en. Last accessed 17.08.2016.

108. Pan American Health Organization. Epidemiological Alert. Zika virus infection -17 March 2016. 2016. Available from:

http://www.paho.org/hq/index.php?option=com_docman\&task=doc_view\&ltemid=270\&gid=33768\&lang=en. Last accessed 16.08.2016.

109. Pan American Health Organization. Epidemiological Update. Zika virus infection - 21 April 2016. 2016. Available from:

http://www.paho.org/hq/index.php?option=com_docman\&task=doc_view\&ltemid=270\&gid=34243\&lang=en. Last accessed 17.08.2016.

110. Thomas DL, Sharp TM, Torres J, Armstrong PA, Munoz-Jordan J, Ryff KR, et al. Local Transmission of Zika Virus--Puerto Rico, November 23, 2015-January 28, 2016. MMWR Morb Mortal Wkly Rep. 2016;65(6):154-8. Epub 2016/02/20. doi: 10.15585/mmwr.mm6506e2. PubMed PMID: 26890470.

111. Reyna-Villasmil E, Lopez-Sanchez G, Santos-Bolivar J. [Guillain-Barre syndrome due to Zika virus during pregnancy]. Med Clin (Barc). 2016;146(7):331-2. Epub 2016/03/08. doi: 10.1016/j.medcli.2016.02.002. PubMed PMID: 26947168.

112. Cao-Lormeau VM, Blake A, Mons S, Lastere S, Roche C, Vanhomwegen J, et al. Guillain-Barre Syndrome outbreak associated with Zika virus infection in French Polynesia: a case-control study. Lancet. 2016;387(10027):1531-9. Epub 2016/03/08. doi: 10.1016/S0140-6736(16)00562-6. PubMed PMID: 26948433. 
113. Roze B, Najioullah F, Ferge JL, Apetse K, Brouste Y, Cesaire R, et al. Zika virus detection in urine from patients with Guillain-Barre syndrome on Martinique, January 2016. Euro Surveill. 2016;21(9). Epub 2016/03/12. doi: 10.2807/1560-7917.ES.2016.21.9.30154. PubMed PMID: 26967758.

114. Lucchese G, Kanduc D. Zika virus and autoimmunity: From microcephaly to Guillain-Barre syndrome, and beyond. Autoimmun Rev. 2016;15(8):801-8. Epub 2016/03/29. doi: 10.1016/j.autrev.2016.03.020. PubMed PMID: 27019049.

115. Craig AT, Butler MT, Pastore R, Paterson BJ, Durrheim DN. Update on Zika virus transmission in the Pacific islands, 2007 to February 2016 and failure of acute flaccid paralysis surveillance to signal Zika emergence in this setting. Bull World Health Organ. 2016. doi: 10.2471/blt.16.171892.

116. Watrin L, Ghawche F, Larre P, Neau JP, Mathis S, Fournier E. Guillain-Barre Syndrome (42 Cases) Occurring During a Zika Virus Outbreak in French Polynesia. Medicine (Baltimore). 2016;95(14):e3257. Epub 2016/04/09. doi: 10.1097/MD.0000000000003257. PubMed PMID: 27057874.

117. Fontes CA, Dos Santos AA, Marchiori E. Magnetic resonance imaging findings in Guillain-Barre syndrome caused by Zika virus infection. Neuroradiology. 2016;58(8):837-8. Epub 2016/04/14. doi: 10.1007/s00234-016-1687-9. PubMed PMID: 27067205.

118. Brasil P, Sequeira PC, Freitas AD, Zogbi HE, Calvet GA, de Souza RV, et al. Guillain-Barre syndrome associated with Zika virus infection. Lancet. 2016;387(10026):1482. Epub 2016/04/27. doi: 10.1016/S0140-6736(16)30058-7. PubMed PMID: 27115821.

119. Kassavetis P, Joseph JM, Francois R, Perloff MD, Berkowitz AL. Zika virus-associated Guillain-Barre syndrome variant in Haiti. Neurology. 2016;87(3):3367. Epub 2016/05/11. doi: 10.1212/WNL.0000000000002759. PubMed PMID: 27164708.

120. Duijster JW, Goorhuis A, van Genderen PJ, Visser LG, Koopmans MP, Reimerink JH, et al. Zika virus infection in 18 travellers returning from Surinam and the Dominican Republic, The Netherlands, November 2015-March 2016. Infection. 2016. Epub 2016/05/23. doi: 10.1007/s15010-016-0906-y. PubMed PMID: 27209175 .

121. van den Berg B, van den Beukel JC, Alsma J, van der Eijk AA, Ruts L, van Doorn PA, et al. [Guillain-Barre syndrome following infection with the Zika virus]. Ned Tijdschr Geneeskd. 2016;160(0):D155. Epub 2016/05/28. PubMed PMID: 27229696.

122. Yung CFT, K. C. Guillain-Barre Syndrome and Zika Virus: Estimating Attributable Risk to Inform Intensive Care Capacity Preparedness. Clin Infect Dis. 2016. Epub 2016/05/27. doi: 10.1093/cid/ciw355. PubMed PMID: 27225243.

123. Jackson BR, Zegarra JA, Lopez-Gatell H, Sejvar J, Arzate F, Waterman S, et al. Binational outbreak of Guillain-Barre syndrome associated with Campylobacter jejuni infection, Mexico and USA, 2011. Epidemiol Infect. 2014;142(5):1089-99. doi: 10.1017/S0950268813001908. PubMed PMID: 23924442. 
124. McCarthy N, Giesecke J. Incidence of Guillain-Barre syndrome following infection with Campylobacter jejuni. Am J Epidemiol. 2001;153(6):610-4. PubMed PMID: 11257070.

[125 not part of this body of evidence]

126. Mishu B, Blaser MJ. Role of infection due to Campylobacter jejuni in the initiation of Guillain-Barre syndrome. Clin Infect Dis. 1993;17(1):104-8. PubMed PMID: 8353228.

127. Rees JH, Soudain SE, Gregson NA, Hughes RA. Campylobacter jejuni infection and Guillain-Barre syndrome. N Engl J Med. 1995;333(21):1374-9. doi: 10.1056/NEJM199511233332102. PubMed PMID: 7477117.

128. Carod-Artal FJ, Wichmann O, Farrar J, Gascon J. Neurological complications of dengue virus infection. Lancet Neurol. 2013;12(9):906-19. Epub 2013/08/21. doi: 10.1016/S1474-4422(13)70150-9. PubMed PMID: 23948177.

129. Sejvar JJ, Bode AV, Marfin AA, Campbell GL, Ewing D, Mazowiecki M, et al. West Nile virus-associated flaccid paralysis. Emerg Infect Dis. 2005;11(7):1021-7. doi: 10.3201/eid1107.040991. PubMed PMID: 16022775; PubMed Central PMCID: PMC3371783.

130. Xiang JY, Zhang YH, Tan ZR, Huang J, Zhao YW. Guillain-Barre syndrome associated with Japanese encephalitis virus infection in China. Viral Immunol. 2014;27(8):418-20. doi: 10.1089/vim.2014.0049. PubMed PMID: 25140441.

131. Ravi V, Taly AB, Shankar SK, Shenoy PK, Desai A, Nagaraja D, et al. Association of Japanese encephalitis virus infection with Guillain-Barre syndrome in endemic areas of south India. Acta Neurol Scand. 1994;90(1):67-72. PubMed PMID: 7941960.

132. McMahon AW, Eidex RB, Marfin AA, Russell M, Sejvar JJ, Markoff L, et al. Neurologic disease associated with 17D-204 yellow fever vaccination: a report of 15 cases. Vaccine. 2007;25(10):1727-34. doi: 10.1016/j.vaccine.2006.11.027. PubMed PMID: 17240001.

133. Solomon T, Kneen R, Dung NM, Khanh VC, Thuy TT, Ha DQ, et al. Poliomyelitis-like illness due to Japanese encephalitis virus. Lancet. 1998;351(9109):1094-7. doi: 10.1016/S0140-6736(97)07509-0. PubMed PMID: 9660579.

134. Chung CC, Lee SS, Chen YS, Tsai HC, Wann SR, Kao CH, et al. Acute flaccid paralysis as an unusual presenting symptom of Japanese encephalitis: a case report and review of the literature. Infection. 2007;35(1):30-2. doi: 10.1007/s15010-007-6038-7. PubMed PMID: 17297587.

135. Argall KG, Armati PJ, King NJ, Douglas MW. The effects of West Nile virus on major histocompatibility complex class I and II molecule expression by Lewis rat Schwann cells in vitro. J Neuroimmunol. 1991;35(1-3):273-84. PubMed PMID: 1955569. 
136. Loshaj-Shala A, Regazzoni L, Daci A, Orioli M, Brezovska K, Panovska AP, et al. Guillain Barre syndrome (GBS): new insights in the molecular mimicry between C. jejuni and human peripheral nerve (HPN) proteins. J Neuroimmunol. 2015;289:168-76. doi: 10.1016/j.jneuroim.2015.11.005. PubMed PMID: 26616887.

137. Meyer Sauteur PM, Huizinga R, Tio-Gillen AP, Roodbol J, Hoogenboezem T, Jacobs E, et al. Mycoplasma pneumoniae triggering the Guillain-Barre syndrome: A case-control study. Ann Neurol. 2016. doi: 10.1002/ana.24755. PubMed PMID: 27490360.

138. Tseng YF, Wang CC, Liao SK, Chuang CK, Chen WJ. Autoimmunity-related demyelination in infection by Japanese encephalitis virus. J Biomed Sci. 2011;18:20. doi: 10.1186/1423-0127-18-20. PubMed PMID: 21356046; PubMed Central PMCID: PMC3056755. 